\title{
PERSEPSI MASYARAKAT TERHADAP KONFLIK MACAN TUTUL JAWA DENGAN WARGA SEKITAR SUAKA MARGASATWA GUNUNG SAWAL
}

\section{(Perception Analysis on the Conflict Between Javan Leopard and Community Around Mount Sawal Wildlife Reserve)}

\author{
Andina Agustia Dewanti \& Hero Marhaento \\ Departemen Konservasi Sumberdaya Hutan, Fakultas Kehutanan, Universitas Gadjah Mada, J1. Agro 1 \\ Bulaksumur, Yogyakarta 55281, Indonesia;e-mail: andinaadewanti@gmail.com, marhaento@ugm.ac.id
}

Diterima 20 Agustus 2020, direvisi 22 Juli 2021, disetujui 22 Juli 2021

\begin{abstract}
Mount Sawal Wildlife Reserve is known as one of the places that has the highest number of conflict cases between javan leopard and human in Indonesia. There were 38 conflict cases recorded in the period of 2001-2016 with the highest number of cases occurring in Kertamandala and Cikupa Villages, Ciamis District, West Java. This study assessed the community perception of those two villages towards the conflict by using Q-method in combination with the R-Studio statistics to analyze the data. There were 19 participants who were tested with 16 consent statements called $Q$-sorting were ranked based on approval scale. The results showed that the community perceptions of conflict can be grouped into three, namely: 1) the importance to preserve the existence of javan leopards, 2) wildlife conflict management is a shared responsibility between communities and authorities, and 3) in the future, wildlife conflicts must not take place again. In addition, all participants shared consensus that the community do not accept the existence of javan leopard in their village area and they also agreed that conservation authorities have taken actions to deal with the conflict.
\end{abstract}

Keywords: Conflict; wildlife; javan leopard; perception; Mount Sawal Wildlife Reserve.

\begin{abstract}
ABSTRAK
Suaka Margasatwa Gunung Sawal dikenal sebagai salah satu tempat yang memiliki jumlah kasus tertinggi dalam konflik antara macan tutul jawa dan manusia di Indonesia. Tercatat sebanyak 38 kasus konflik pada periode 2001-2016 dengan jumlah kasus tertinggi terjadi di Desa Kertamandala dan Desa Cikupa, Kabupaten Ciamis, Jawa Barat. Penelitian bertujuan untuk menilai persepsi masyarakat di kedua desa tersebut terhadap konflik yang terjadi antara macan tutul jawa dan manusia, menggunakan metode Q. Terdapat 19 partisipan yang diuji dengan 16 pernyataan persetujuan yang dinamakan $Q$-sorting. Partisipan merupakan perwakilan masyarakat desa yang pernah mengalami konflik langsung dengan macan tutul jawa. Hasil penelitian menunjukkan bahwa terdapat tiga kelompok persepsi yang muncul di masyarakat yaitu: 1) pentingnya menjaga kelestarian macan tutul jawa, 2) penanganan konflik satwa liar merupakan tanggung jawab bersama antara masyarakat dengan pengelola kawasan, dan 3) masyarakat tidak menghendaki terjadinya konflik di masa mendatang. Selain itu, terbentuk konsensus di antara partisipan yang menyebut bahwa masyarakat tidak menerima keberadaan macan tutul jawa di wilayah desanya dan mereka setuju bahwa pihak pengelola kawasan sudah melakukan tindakan untuk menangani konflik yang terjadi.
\end{abstract}

Kata kunci: Konflik; satwa liar; macan tutul jawa; persepsi; Suaka Margasatwa Gunung Sawal. 


\section{PENDAHULUAN}

Macan tutul jawa (Panthera pardus) merupakan satwa endemik Pulau Jawa yang dilindungi oleh Pemerintah Indonesia. Macan tutul jawa memiliki status konservasi vulnerable atau rentan yang ditetapkan oleh The International Union for Conservation of Nature (IUCN) karena populasinya yang terus menurun (WWF, 2018). Salah satu faktor penyebab turunnya populasi satwa tersebut adalah adanya konflik dengan manusia. Konflik antara macan tutul jawa dan manusia dapat terjadi karena adanya persinggungan ruang untuk hidup (Gunawan, Iskandar, Sihombing \& Wienanto, 2017).

Di Indonesia, kasus konflik macan tutul jawa dengan manusia yang paling tinggi terjadi di Gunung Sawal, Kabupaten Ciamis, Provinsi Jawa Barat (Tim Kolaboratif Penyelamatan Macan Tutul Jawa, 2017). Lebih dari separuh kawasan Gunung Sawal merupakan kawasan suaka margasatwa yang berbatasan langsung dengan kawasan Perum Perhutani dan wilayah desa (BBKSDA Jawa Barat, 2016). Menurut Tim Kolaboratif Penyelamatan Macan Tutul Jawa (2017), Gunung Sawal memiliki 51 catatan kasus selama periode 2001-2016. Kasus-kasus tersebut berupa macan tutul jawa keluar dari kawasan hutan dimana 75\% dari kasus tersebut menimbulkan konflik. Bentuk konflik yang terjadi antara lain pemangsaan ternak $(67 \%)$ dan penangkapan atau pembunuhan macan tutul jawa (8\%). Frekuensi kasus konflik tertinggi terjadi di Desa Kertamandala, Kecamatan Panjalu dengan 10 kejadian konflik dan di Desa Cikupa, Kecamatan Lumbung dengan 9 kejadian konflik. Kedua desa tersebut secara administratif masuk di Kabupaten Ciamis, Provinsi Jawa Barat.

Hill, Osborn, \& Plumptre (2002) menyatakan bahwa solusi dari suatu konflik adalah dengan memahami persepsi dari seluruh individu yang terlibat konflik. Persepsi merupakan cara seseorang dalam menanggapi, memahami, dan menafsirkan sesuatu (Ntuli, Jagers, Linell, Sjöstedt, \& Muchapondwa, 2019; Pham \& Lee, 2017). Menurut Qiong (2017), persepsi merupakan pendapat, gagasan, dan cara pandang dalam menyimpulkan suatu objek atau peristiwa (Situmorang, Silalahi, \& Kuswanda, 2020). Persepsi selanjutnya akan diterjemahkan menjadi sebuah sikap atau perilaku seiring berjalannya waktu (Beedel \& Rehman, 2000; Ntuli et al., 2019).

Gunawan et al. (2017), Partasasmita et al. (2016), dan Gomez \& Shepherd (2021) menekankan pentingnya pemahaman masyarakat sekitar hutan dalam mengurangi risiko konflik antara macan tutul jawa dengan warga. Pada kejadian konflik satwa liar dengan manusia, persepsi masyarakat memegang peran yang penting karena dapat mempengaruhi tingkat toleransi dalam pengaduan dan solusi yang diusulkan (Hill et al., 2002; Treves, Naughton-Treves, \& Wallace, 2006). Jika individu masyarakat memiliki persepsi yang positif terhadap satwa tertentu, individu tersebut akan memiliki keinginan untuk mengubah perilakunya terhadap satwa liar (Shafie, Sah, Mutalib, \& Fadzly, 2017). Pada konteks pengelolaan kawasan konservasi, informasi persepsi masyarakat di sekitar kawasan (desa penyangga) terhadap konflik satwa liar yang terjadi selanjutnya dapat digunakan dalam menyusun perencanaan prioritas kegiatan pengelolaan kawasan (Gandiwa et al., 2014).

Penelitian ini bertujuan untuk mengetahui persepsi warga Desa Kertamandala dan Desa Cikupa di Kabupaten Ciamisyangmerupakan desa penyangga Suaka Margasatwa Gunung Sawal tentang konflik masyarakat dengan macan tutul jawa. Penelitian ini berbeda dari penelitian-penelitian sebelumnya yang terkait persepsi masyarakat di mana dalam penelitian ini digunakan metode $\mathrm{Q}$ yang merupakan metode pengukuran persepsi dengan pendekatan semi kuantitatif. Metode Q dipilih karena metode ini dapat mengorelasikan pendapat para responden 
untuk mengetahui adanya pandangan yang sama atau berbeda terhadap suatu objek (Brown, 1993). Dalam bidang konservasi, metode Q pernah digunakan dalam memahami konflik manusia dan alam, manajemen spesies dengan status terancam punah, atau diskusi mengenai strategi dalam organisasi konservasi tersebut (Zabala, Sandbrook, \& Mukherjee, 2018). Namun demikian, Zabala et al. (2018) menyampaikan bahwa ulasan mengenai pemakaian metode $\mathrm{Q}$ dalam bidang konservasi perlu diperbanyak melalui studi kasus di berbagai wilayah dengan kondisi sosial masyarakat yang bervariasi.

\section{METODE PENELITIAN}

\section{A. Waktu dan Lokasi Penelitian}

Penelitian dilakukan sejak Agustus 2019 hingga Februari 2020 di Desa Kertamandala dan Desa Cikupa. Lokasi penelitian disajikan dalam Gambar 1.
Secara administratif, Desa Kertamandala di Kecamatan Panjalu dan Desa Cikupa di Kecamatan Lumbung merupakan wilayah Kabupaten Ciamis, Jawa Barat.

\section{B. Pengumpulan Data}

Partisipan ditentukan secara sensus terhadap masyarakat yang pernah mengalami konflik dengan macan tutul jawa di kedua desa. Jumlah partisipan sebanyak 19 orang, terdiri atas 10 orang dari Desa Kertamandala dan 9 orang dari Desa Cikupa. Pengambilan data menggunakan peralatan berupa voice recorder, kamera, kuesioner, dan GPS.

\section{Pengolahan Data}

Pengolahan data dilakukan dengan metode Q dengan bantuan perangkat lunak RStudio. Metode Q ini memiliki kemiripan dengan pendekatan skala Likert tetapi memiliki keunggulan yaitu dapat menghindari kecenderungan partisipan untuk memilih nilai tengah dibanding

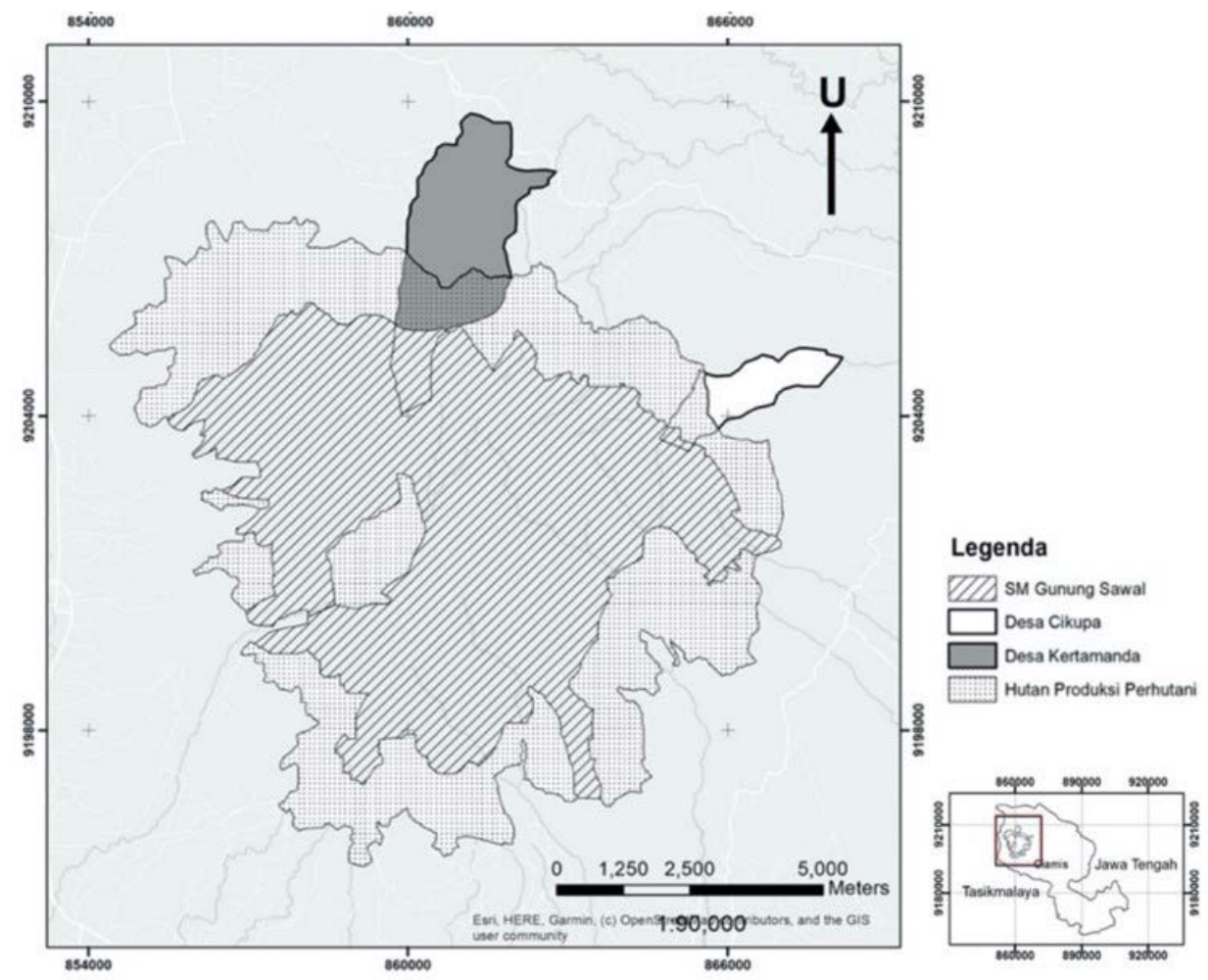

Gambar 1 Peta lokasi penelitian di sekitar Suaka Margasatwa Gunung Sawal Figurel Map of research location in the surrounding of Mount Sawal Wildlife Reserve. 
nilai ekstrim (Rijneveld \& Marhaento, 2020). Kendati demikian, metode ini memiliki kelemahan dalam hal validitas dan reliabilitas data. Untuk mengatasi hal ini, validitas dan reliabilitas data dilakukan dengan cara meminta partisipan memeriksa kembali peringkat pada set pernyataan yang diberikan dan partisipan dapat mengubah sampai sesuai dengan sudut pandang partisipan (Bashatah, 2016). Selain itu, metode Q ini tidak memberikan banyak kebebasan interpretasi persepsi partisipan karena persepsi yang dihasilkan terbatas pada pernyataan yang diberikan kepada partisipan (Zabalaet al., 2018).

Metode Q merupakan alat ukur yang terstruktur untuk memperoleh pandangan para pihak tentang suatu isu (Brown, 1993; Zabala et al., 2018). Metode Q dipilih karena dapat menerjemahkan hal yang abstrak menjadi hal yang lebih sistematis, teratur, dan terukur dengan cara mengorelasikan para responden sehingga menunjukkan sudut pandang yang sama dan berbeda pada suatu objek (Brown, 1993). Selain itu, metode Q tidak membutuhkan sampel yang besar karena dapat berdasar pada keterwakilan partisipan yang mewakili spektrum pendapat yang berbeda (Exel \& Graaf, 2005; Rijneveld \& Marhaento, 2020).

Sebelum pengambilan data di lapangan, tim peneliti mempersiapkan set kartu pernyataan $(Q$-set) yang berisi pernyataanpernyataan yang akan digunakan. QMethod Software (2021) menyatakan bahwa $Q$-set didapatkan dari berbagai macam opini, perspektif, atau pernyataan seputar topik penelitian, dalam hal ini penelitian konflik satwa liar dengan manusia. Pernyataan dalam $Q$-set dapat dikumpulkan dari berbagai sumber seperti wawancara, studi literatur, dan media sosial. Setelah terkumpul, pernyataan-pernyataan tersebut disaring menjadi beberapa pernyataan yang mewakili topik penelitian. Selain cara tersebut, pemilihan pernyataan juga dapat dilakukan dengan mengategorikan pernyataan-pernyataan ke dalam subtopik (Zabalaet al., 2018).

Pada proses pengambilan data, partisipan memberikan peringkat pada set pernyataan berdasarkan tingkat persetujuannya. Pemberian peringkat dilakukan secara bersamaan dan terkait satu sama lain sehingga dapat mendorong partisipan untuk menentukan pilihan kritis (Pirard, Petit, Baral, \& Achdiawan, 2016). Terdapat 16 pernyataan yang diuji, terdiri dari tiga bagian utama yaitu interaksi partisipan dengan macan tutul jawa, perilaku partisipan terhadap macan tutul jawa, dan penanganan konflik antara macan tutul jawa dan manusia. Pemilihan pernyataan mengacu pada penelitian-penelitian yang sudah pernah dilakukan sebelumnya tentang konflik satwa dengan manusia (Hazarika \& Dutta, 2018; Mudumba, 2011; Rust, 2017). Tabel 1 menunjukkan pernyataan yang diuji dengan metode $\mathrm{Q}$.

Pengumpulan data pada metode Q dilakukan dengan $Q$-sorting oleh partisipan. Prosedur $Q$-sorting dilakukan dalam tiga tahapan sebagai berikut:

1. Partisipan mengurutkan 16 kartu pernyataan menjadi tiga kelompok yaitu pernyataan yang disetujui, pernyataan yang tidak disetujui, dan pernyataan yang netral/tidak yakin.

2. Partisipan meletakkan kartu pada $Q$-grid (Gambar 2) dengan skor -3 sampai +3 . Partisipan mengambil kartu pernyataan dari kelompok setuju dan memilih kartu yang paling disetujui, begitu pula dengan kelompok tidak setuju. Setelah itu, partisipan mengambil kartu dari kelompok setuju, pilih yang paling disetujui tetapi tidak sekuat pilihan pertama, begitu pula dengan kelompok tidak setuju. Proses ini berlanjut sampai posisi penempatan di tengah 0 (poin netral) dan sampai semua pernyataan diposisikan dari kiri-kanan.

3. Partisipan diminta melihat kembali pilihan posisi pernyataan dan ditegaskan 
Tabel 1 Pernyataan yang diuji untuk mengetahui persepsi terhadap konflik

Table 1 Statements tested for assessing the perception towards conflict.

\begin{tabular}{|c|c|c|}
\hline Kriteria (Criteria) & No. & Pernyataan (Statement) \\
\hline $\begin{array}{l}\text { Interaksi partisipan dengan } \\
\text { macan tutul jawa }\end{array}$ & $\begin{array}{l}2 \\
3\end{array}$ & $\begin{array}{l}\text { Interaksi saya dengan macan tutul jawa terjadi karena jumlah macan tutul } \\
\text { jawa di hutan meningkat. } \\
\text { Saya memaklumi konflik yang terjadi karena tinggal di dekat hutan. } \\
\text { Intensitas interaksi antara macan tutul jawa dengan masyarakat saat ini } \\
\text { semakin meningkat. } \\
\text { Sosialisasi mengenai tindakan yang harus dilakukan ketika bertemu } \\
\text { dengan macan tutul jawa penting untuk diberikan kepada masyarakat. }\end{array}$ \\
\hline $\begin{array}{l}\text { Perilaku partisipan } \\
\text { terhadap macan tutul jawa }\end{array}$ & $\begin{array}{l}5 \\
6\end{array}$ & $\begin{array}{l}\text { Menjaga kelestarian macan tutul jawa di hutan, penting untuk dilakukan. } \\
\text { Sosialisasi mengenai konservasi, ekologi, dan nilai macan tutul jawa } \\
\text { kepada masyarakat cukup penting. } \\
\text { Saya menerima keberadaan macan tutul jawa di hutan sekitar pemukiman } \\
\text { tempat tinggal saya. } \\
\text { Menurut saya, macan tutul jawa memberikan keuntungan dan manfaat } \\
\text { (ekonomi, pendidikan, atau nilai satwa lainnya). } \\
\text { Serangan manusia terhadap macan tutul jawa dapat dilakukan ketika } \\
\text { satwa memasuki wilayah masyarakat. }\end{array}$ \\
\hline $\begin{array}{l}\text { Penanganan konflik macan } \\
\text { tutul jawa dengan manusia }\end{array}$ & $\begin{array}{l}10 \\
11\end{array}$ & $\begin{array}{l}\text { Saya tahu bahwa ada pihak pemerintah untuk menangani macan tutul } \\
\text { jawa yang memasuki kawasan permukiman masyarakat. } \\
\text { Pihak konservasi sudah melakukan tindakan untuk menangani konflik } \\
\text { manusia dengan macan tutul jawa di desa saya. } \\
\text { Pihak konservasi merupakan pihak yang bertanggung jawab dalam } \\
\text { konflik. } \\
\text { Cara letal (membunuh) lebih baik daripada cara non-letal untuk menangani } \\
\text { konflik macan tutul jawa dengan manusia. } \\
\text { Masyarakat di desa telah berusaha menghindari/mengurangi konflik } \\
\text { dengan macan tutul jawa dengan melakukan tindakan preventif. } \\
\text { Akses untuk melaporkan konflik macan tutul jawa dengan manusia sangat } \\
\text { mudah untuk dilakukan masyarakat yang terkena konflik. } \\
\text { Saya bersedia berpartisipasi dalam pengelolaan konflik macan tutul jawa } \\
\text { dengan manusia di tempat tinggal saya. }\end{array}$ \\
\hline
\end{tabular}

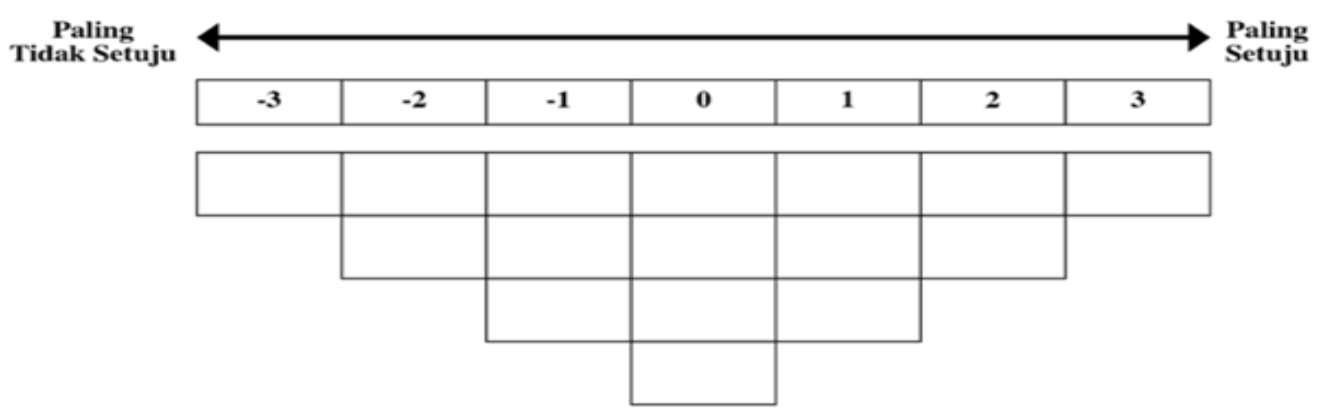

Gambar 2 Q-grid yang berbentuk seperti kurva distribusi normal

Figure 2 Q-grid with a bell-shaped curve.

kembali bahwa partisipan dapat mengubah susunan posisi sampai partisipan tersebut yakin bahwa urutan yang dipilih sudah mewakili pandangan partisipan.
Data yang diperoleh kemudian dicatat dalam bentuk matriks dengan pernyataan sebagai baris, partisipan sebagai kolom, dan nilai sel dalam matriks berupa nilai yang diberikan partisipan untuk setiap pernyataan. 
Untuk menganalisis data hasil Q-sorting, digunakan perangkat lunak RStudio dengan paket $Q$-method. Tahap lengkap analisis Q menggunakan RStudio dapat dilihat dalam Zabala (2019).

Tahapan analisis dimulai dengan memuat paket $Q$-method yang sudah dipasang di $R$ Studio, kemudian memanggil data $Q$-sort yang dimiliki. Selanjutnya dilakukan analisis korelasi antara sejumlah $Q$-sort dan dicari faktor pemuatnya dengan menentukan jumlah faktor yang ingin dihasilkan. Analisis ini menggunakan teknik Principal Components Analysis untuk reduksi data, koefisien korelasi Pearson, dan rotasi varimax untuk menghasilkan tiga faktor yang selanjutnya dapat membantu menentukan kelompok persepsi yang muncul.

\section{III.HASIL DAN PEMBAHASAN}

Hasil analisis persepsi dengan metode Q menghasilkan tiga kelompok persepsi atau yang disebut sebagai faktor. Masingmasing kelompok persepsi (faktor) merupakan hasil pengelompokan dari skor pernyataan-pernyataan yang muncul. Tabel 2 menunjukkan skor hasil analisis $Q$-sorting yang telah dikelompokkan menjadi tiga faktor yang didapatkan dari hasil analisis menggunakan RStudio.

Dari hasil pengelompokan persepsi tersebut, dapat diketahui bahwa faktor 1 adalah terkait kelompok persepsi yang berpendapat "pentingnya menjaga kelestarian macan tutul jawa". Kelompok persepsi ini menekankan bahwa sosialisasi terkait macan tutul jawa seperti upaya konservasi, ekologi, dan nilai satwa sangat penting untuk diberikan kepada masyarakat (pernyataan 6, skor Q+3). Selain itu, partisipan juga mengharapkan adanya sosialisasi terkait tindakan yang harus dilakukan ketika masyarakat bertemu dengan macan tutul jawa (pernyataan 4, skor $\mathrm{Q}+2$ ). Pada penanganan konflik yang terjadi, partisipan tidak setuju jika penyelesaiannya menggunakan cara letal atau membunuh macan tutul jawa (pernyataan 13, skor Q -3). Persepsi ini menunjukkan bahwa menjaga kelestarian macan tutul jawa merupakan

Tabel 2 Skor faktor pada tiap pernyataan

Table 2 Factor scores for each statement

\begin{tabular}{cccc}
\hline $\begin{array}{c}\text { No. pernyataan } \\
\text { (Statement } \text { number })\end{array}$ & $\begin{array}{c}\text { Faktor 1 } \\
(\text { Factor } 1)\end{array}$ & $\begin{array}{c}\text { Faktor } 2 \\
(\text { Factor } 2)\end{array}$ & $\begin{array}{c}\text { Faktor 3 } \\
(\text { Factor 3) }\end{array}$ \\
\hline 1 & -2 & +2 & -1 \\
2 & +1 & -1 & -3 \\
3 & -1 & 0 & +1 \\
4 & +2 & +1 & 0 \\
5 & +2 & +2 & 0 \\
6 & +3 & +1 & -1 \\
7 & -2 & -2 & -2 \\
8 & -1 & -3 & -2 \\
9 & +1 & -2 & 0 \\
10 & 0 & +3 & +1 \\
11 & 0 & +1 & 0 \\
12 & -1 & -1 & +1 \\
13 & -3 & -1 & -1 \\
14 & 0 & 0 & +2 \\
15 & 0 & 0 & +2 \\
16 & +1 & 0 & +3 \\
\hline
\end{tabular}

Keterangan (Remarks):

Nilai paling tinggi adalah +3 ,paling setuju, dan paling rendah adalah -3 , paling tidak setuju (The highest score is +3 , strongly agree, and the lowest score is -3 , strongly disagree) 
suatu hal yang penting (pernyataan 5 , skor Q +2 ). Menurut partisipan, menjaga kelestarian macan tutul jawa berguna sebagai sumber pengetahuan untuk generasi selanjutnya dan keberadaan macan tutul jawa bermanfaat untuk mencegah pemburu memasuki hutan.

Faktor 2 adalah kelompok persepsi bahwa "penanganan konflik merupakan tanggung jawab bersama antara masyarakat dengan pengelola kawasan". Kelompok persepsi ini menjelaskan bahwa partisipan sudah memahami bahwa pihak pemerintah melalui Balai Besar Konservasi Sumber Daya Alam (BBKSDA) Jawa Barat adalah pihak yang berwenang dalam penanganan konflik (pernyataan 10, skor Q +3 ). Namun demikian, hanya sedikit partisipan yang berpendapat bahwa pihak BBKSDA Jawa Barat sudah melakukan tindakan penanganan konflik (pernyataan 11, skor Q+1). Partisipan menyadari bahwa penanganan konflik macan tutul jawa dengan masyarakat tidak hanya merupakan tanggung jawab pihak BBKSDA Jawa Barat tetapi juga tanggung jawab mereka (pernyataan 12, skor Q -1). Partisipan merasa bahwa keberadaan macan tutul jawa tidak memberikan manfaat untuk mereka (pernyataan 8, skor Q -3) namun mereka berpendapat bahwa melakukan penyerangan terhadap macan tutul jawa bukanlah hal yang tepat untuk dilakukan (pernyataan 9, skor Q -2) dan mereka tidak menyetujui penggunaan cara letal untuk penanganan konflik (pernyataan 13, skor Q $-1)$.

Faktor 3 adalah kelompok persepsi yang menunjukkan "masyarakat tidak menghendaki terjadinya konflik lagi di masa mendatang". Kelompokpersepsi inimemiliki pandangan netral akan pentingnya menjaga kelestarian macan tutul jawa (pernyataan 5, skor Q 0) tetapi tidak memaklumi konflik yang terjadi di desa karena berada di dekat hutan (pernyataan 2, skor Q -3) ataupun menerima keberadaan macan tutul jawa di hutan sekitar tempat tinggal mereka (pernyataan 7, skor Q -2). Seluruh partisipan memiliki pekerjaan sebagai petani dengan letak sawah atau ladang garapan yang berdekatan dengan hutan sehingga peluang untuk bertemu langsung dengan macan tutul jawa cukup tinggi. Persepsi ini menggambarkan macan tutul jawa sebagai satwa yang tidak memberikan keuntungan dan manfaat untuk masyarakat (pernyataan 8, skor Q -2). Seperti pernyataan salah satu partisipan, J (inisial) dari Desa Cikupa yang berpendapat bahwa macan tutul jawa merupakan hama. Partisipan juga merasa sosialisasi mengenai macan tutul jawa tidak penting untuk diberikan kepada masyarakat (pernyataan 6, skor Q -1).

Selain menghasilkan ketiga kelompok persepsi tersebut, diketahui juga pernyataan

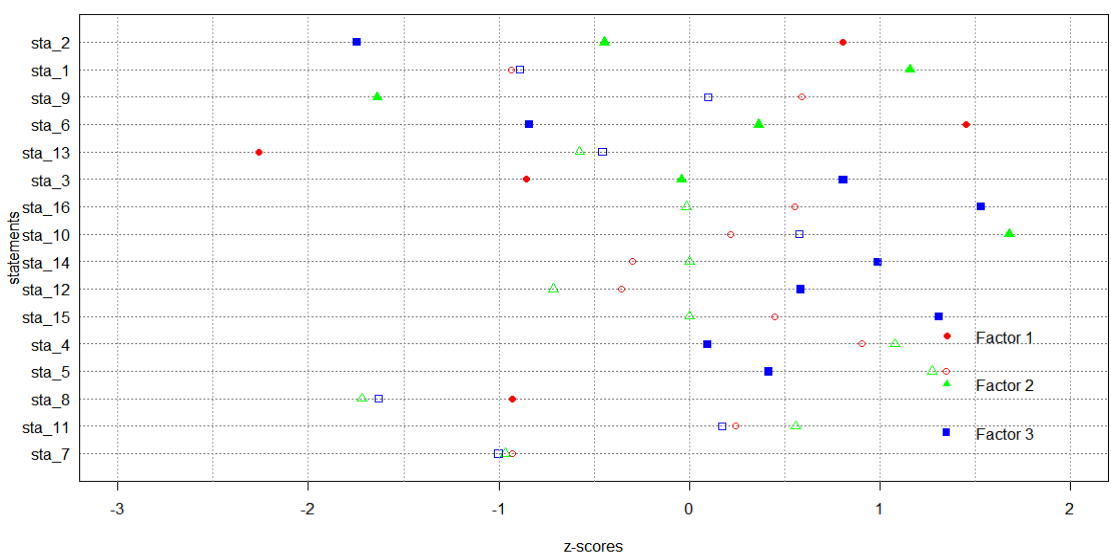

Gambar 3 Grafik plot letak ketiga faktor pada setiap pernyataan di mana sumbu x menunjukkan nilai z dan sumbu y menunjukkan pernyataan yang digunakan dalam penelitian

Figure 3 Plot graph of the location of all three factors in each statement, which $x$-axis shows z-score and y-axis shows statements used in the research. 
yang memiliki konsensus dan diskonsensus dari seluruh partisipan. Hal ini dapat dilihat pada Gambar 3 yang merupakan grafik titik letak nilai $\mathrm{z}$ (z-score) dari ketiga faktor. Koordinat $\mathrm{x}$ pada grafik menunjukkan nilai $\mathrm{z}$ dan koordinat y menunjukkan pernyataanpernyataan yang digunakan dalam penelitian.

Jika ketiga titik pada pernyataan $\mathrm{x}$ terletak saling berjauhan, menandakan ketiga faktor memiliki pendapat yang berbeda tentang pernyataan tersebut. Jika ketiga titik pada pernyataan $\mathrm{x}$ terletak berdekatan, menandakan ketiga faktor memiliki konsensus atau kesepakatan bersama.

Konsensus terjadi pada pernyataan 7 "saya menerima keberadaan macan tutul jawa di hutan sekitar permukiman tempat tinggal saya" dan pernyataan 11"pihak konservasi sudah melakukan tindakan untuk menangani konflik manusia dengan macan tutul jawa di desa saya". Pernyataan 7 menyatakan ketidaksetujuan yang kuat dengan nilai yang sama (skor Q pada faktor 1, 2, dan 3 adalah $-1,-1,-1)$. Hal ini menandakan bahwa partisipan dari kedua desa tidak menerima keberadaan macan tutul jawa di hutan sekitar permukiman tempat tinggal mereka yang menyebabkan partisipan tidak merasa aman. Konsensus pada pernyataan 11 (nilai: 0, 1, 0) menyatakan bahwa partisipan dari kedua desa setuju pengelola kawasan (BBKSDA Jawa Barat) sudah melakukan tindakan untuk menangani konflik manusia dengan macan tutul jawa di kedua desa.

Pernyataan yang mengalami diskonsensus atau perbedaan persepsi secara nyata adalah pernyataan 2, 3, dan 6. Pernyataan 2 (skor Q pada faktor 1, 2, dan 3 adalah 1, 0, -2), yaitu "partisipan memaklumi konflik yang terjadi karena tinggal di dekat hutan" tidak disepakati secara merata oleh ketiga kelompok persepsi. Kelompok persepsi 3 paling tidak setuju dengan pernyataan tersebut (dengan nilai -2), sedangkan kelompok persepsi 1 relatif setuju dengan pernyataan tersebut. Pada pernyataan 3 (skor faktor: $-1,0,1)$, yaitu "intensitas interaksi antara macan tutul jawa dengan masyarakat saat ini semakin meningkat", tidak disetujui oleh kelompok persepsi 1. Seperti yang disampaikan oleh salah satu partisipan, D (inisial) dari Desa Cikupa bahwa "sekarang sudah tidak pernah bertemu lagi dengan macan tutul jawa". Ini berbeda dengan kelompok persepsi 3 yang setuju dengan pernyataan 3 bahwa intensitas interaksi antara macan tutul jawa dengan masyarakat semakin meningkat. Pada pernyataan 6 (skor faktor: 1, 0, -1), yaitu "sosialisasi mengenai konservasi, ekologi, dan nilai macan tutul jawa kepada masyarakat cukup penting" disetujui oleh kelompok persepsi 1 dengan nilai +1 namun tidak disetujui oleh kelompok persepsi 3 dengan nilai -1. Hal ini dapat terjadi karena persepsi kelompok persepsi 3 yang tidak memaklumi konflik sehingga merasa sosialisasi sudah tidak perlu lagi dilakukan.

Dari hasil analisis tersebut terlihat bahwa seluruh partisipan memiliki persepsi yang berbeda-beda dalam memandang konflik macan tutul jawa dengan masyarakat. Persepsi tersebut ada yang positif (kelompok persepsi 1 dan 2) dan negatif (kelompok persepsi 3). Perbedaan persepsi ini hidup di dalam masyarakat dan muncul akibat pengaruh perbedaan pengalaman individu sebagai faktor internal (Rianti \& Garsetiasih, 2017) yang akan menentukan pilihan individu dalam menyikapi konflik yang terjadi (Arifin, Fuady, \& Kuswarno, 2017).

\section{KESIMPULAN DAN SARAN}

\section{A. Kesimpulan}

Persepsi masyarakat Desa Kertamandala dan Desa Cikupa di Kabupaten Ciamis terhadap konflik dengan macan tutul jawa dapat dipetakan dengan baik dengan metode Q. Secara umum, terdapat tiga kelompok persepsi yang muncul di masyarakat, yaitu: 1) pentingnya menjaga kelestarian macan tutul jawa, 2) penanganan konflik 
merupakan tanggung jawab bersama antara masyarakat dengan pengelola kawasan, dan 3) masyarakat tidak menghendaki terjadinya konflik lagi di masa mendatang.

Selain memunculkan tiga kelompok persepsi di mana kelompok 1 dan 2 cenderung memiliki persepsi positif sedangkan kelompok 3 memiliki persepsi negatif, hasil analisis juga menunjukkan bahwa terjadi konsensus dan diskonsensus antarpartisipan. Konsensus atau kesepakatan terjadi pada pernyataan bahwa masyarakat tidak menerima keberadaan macan tutul jawa di sekitar permukiman tempat tinggal mereka dan setuju bahwa pihak pengelola kawasan sudah melakukan tindakan untuk menangani konflik yang terjadi. Diskonsensus atau ketidaksepakatan antarpartisipan terjadi pada pernyataan bahwa partisipan memaklumi konflik yang terjadi, intensitas interaksi antara macan tutul jawa dan masyarakat saat ini, dan pentingnya sosialisasi mengenai konservasi dan ekologi macan tutul jawa.

\section{B. Saran}

Hasil penelitian menunjukkan bahwa pada masyarakat yang terdampak konflik dengan macan tutul jawa di Desa Kertamandala dan Desa Cikupa memiliki persepsi yang berbeda-beda sehingga membutuhkan pendekatan yang lebih baik dalam upaya mitigasi konflik satwa liar dengan manusia di kedua desa tersebut. Masih munculnya persepsi negatif dalam menghadapi konflik macan tutul jawa dengan masyarakat dapat berakibat fatal bagi kedua belah pihak sehingga perlu digalakkan edukasi dan sosialisasi kepada masyarakat mengenai ekologi macan tutul jawa dan cara memitigasi konfliknya.

Peluang untuk meningkatkan keterlibatan masyarakat di kedua desa dalam upaya konservasi macan tutul jawa cukup besar karena terdapat kelompok masyarakat yang memiliki persepsi positif. BBKSDA Jawa Barat sebagai pihak pengelola kawasan
Suaka Margasatwa Gunung Sawal perlu meningkatkan partisipasi masyarakat lokal di Desa Kertamandala dan Desa Cikupa dalam upaya mitigasi konflik macan tutul jawa dengan manusia. Partisipasi ini meliputi kegiatan-kegiatan konservasi macan tutul jawa di dalam dan sekitar kawasan serta mitigasi konflik, mulai dari perencanaan, pelaksanaan, sampai dengan evaluasi sehingga akan menjadi kegiatan yang berkelanjutan.

\section{UCAPAN TERIMA KASIH (ACKNOWLEDGEMENT)}

Penulis mengucapkan terimakasih kepada warga Desa Kertamandala dan Desa Cikupa di Kabupaten Ciamis yang telah berkenan menjadi narasumber dalam penelitian ini. Terimakasih juga kepada Bapak Himawan Sasongko, Nugraha Wirasudarma, Ilham Purwa F., Ona Noerwana, dan para petugas di BKSDA Bidang Wilayah III Ciamis, Resort Konservasi Wilayah XIX Gunung Sawal atas bantuan yang diberikan selama penelitian berlangsung.

\section{DAFTAR PUSTAKA}

Arifin, H. S., Fuady, I., \& Kuswarno, E. (2017). Analisis faktor yang mempengaruhi persepsi mahasiswa terhadap keberadaan Perda Syariah di Kota Serang. Jurnal Penelitian Komonikasi dan Opini Publik, 21(1), 88-101.

Bashatah, L. S. (2016). Q-methodology: What and how. Journal of Research \& Method in Education, 6(5), 37-43.

BBKSDA Jawa Barat. (2016). Suaka Margasatwa Gunung Sawal. Retrieved August 10, 2020 from http://bbksdajabar.ksdae.menlhk.go.id/ wp-content/uploads/2017/08/Profil-Bidwil-3Fix_skw_6_sawal.pdf.

Beedel, J. \& Rehman, T. (2000). Using socialpsychology models to understand farmers' conservation behaviour. Journal of Rural Studies, 16(1), 117-127. https://doi. org/10.1016/S0743-0167(99)00043-1.

Brown, S. (1993). A primer on Q methodology. Operant Subjectivity, 16(3/4), 91-138. 
Exel, J. van \& Graaf, G. de. (2005). Q methodology: A sneak preview. Social Sciences, 2(June), $1-30$.

Gandiwa, E., Zisada-Gandiwa, P., Muboko, N., Libombo, E., Mashapa, C., \& Gwazani, R. (2014). Local people's knowledge and perceptions of wildlife conservation in Southeastern Zimbabwe. Journal of Environmental Protection, 5, 475-481. https://doi.org/10.4236/jep.2014.56050.

Gomez \& Shepherd. (2021). The illegal exploitation of the javan leopard (Panthera pardus melas) and sunda clouded leopard (Neofelis diardi) in Indonesia. Nature Conservation, 43, 25-39. doi: 10.3897/natureconservation.43.59399.

Gunawan, H., Iskandar, S., Sihombing, V. S., \& Wienanto, R. (2017). Conflict between humans and leopards (Panthera pardus melas Cuvier, 1809) in Western Java, Indonesia. Biodiversitas, 18(2), 652-658. doi: 10.13057/ biodiv/d180229.

Hazarika, A. \& Dutta, H. (2018). Perceptions of human-elephant conflict around Abhaypur Reserve Forest in Northeast India. Gajah, 48 (February), 27-29.

Hill, C. M., Osborn, F. V, \& Plumptre, A. J. (2002). Human-wildlife conflict: identifying the problem and possible solutions. Albertine Rift Technical Reports Series, 1(June).

Mudumba, T. (2011). Perceptions and solutions to human wildlife conflicts in and around Murchison falls National Park. Wildlife Conservation Society: New York. Retrieved June 21, 2020 from https://library.wcs.org/doi/ ctl/view/mid/33065/pubid/DMX1633800000. aspx.

Ntuli, H., Jagers, S. C., Linell, A., Sjöstedt, M., \& Muchapondwa, E. (2019). Factors influencing local communities' perceptions towards conservation of transboundary wildlife resources: the case of The Great Limpopo Trans-Frontier Conservation Area. Biodiversity and Conservation, 28. https:// doi.org/10.1007/s10531-019-01809-5.

Partasasmita, R., Shanida, S., Iskandar, J., Noviar, E., Husodo, T., Parikesit, \& Malone, N. (2016). Human-leopard conflict in Girimukti Village, Sukabumi, Indonesia. Biodiversitas, 17(2), 783-790. doi: 10.13057/biodiv/d170255.

Pham, M. H. \& Lee, J. H. (2017). Finding important factors affecting local residents' support for tourism development in Ba Be National Park, Vietnam. Forest Science and Technology, 13(3), 126-132. https://doi.org/10.1080/2158 0103.2017.1354337.
Pirard, R., Petit, H., Baral, H., \& Achdiawan, R. (2016). Dampak hutan tanaman industri di Indonesia: analisis persepsi masyarakat desa di Sumatera, Jawa, dan Kalimantan. Occasional Paper, 153. https://doi. org/10.17528/cifor/006137.

Qiong, O.U.(2017). Abrief introduction to perception. Studies in Literature and Language, 15(4), 18-28. https://doi.org/10.3968/10055.

QMethod Software. (2021). QMethod software. Retrieved April 30, 2021 from https:// qmethodsoftware.com/q-methodology/.

Rianti, A. \& Garsetiasih, R. (2017). Persepsi masyarakat terhadap gangguan gajah sumatera (Elephas maximus sumatranus) di Kabupaten Ogan Komering Ilir. Jurnal Penelitian Sosial dan Ekonomi Kehutanan, 14(2), 83-99. https://doi.org/10.20886/jpse.2017.14.2.8399.

Rijneveld, R. \& Marhaento, H. (2020). Stakeholders' contradicting perceptions on the effects of agroforestry and monocropping systems on water use. Water Practice and Technology, 15(2), 365-373. https://doi.org/10.2166/ wpt.2020.024.

Rust, N. A. (2017). Can stakeholders agree on how to reduce human-carnivore conflict on Namibian livestock farms? A Novel Q-methodology and Delphi Exercise. Oryx, 51(2), 339-346. https://doi.org/10.1017/S0030605315001179.

Shafie, N. J., Sah, S.A. M., Mutalib, A. H.A., \& Fadzly, N. (2017). General perceptions and awareness level among local residents in Penang Island toward bats conservation efforts. Tropical Life Sciences Research, 28(2), 31-44. https://doi. org/10.21315/tlsr2017.28.2.3.

Situmorang, R. O. P., Silalahi, J., \& Kuswanda, W. (2020). Persepsi stakeholder pada pengembangan Pusat Konservasi Gajah di KHDTK Aek Nauli. Jurnal Penelitian Sosial dan Ekonomi Kehutanan, 17(2), 83-100.

Tim Kolaboratif Penyelamatan Macan Tutul Jawa. (2017). Kajian habitat, populasi dan sosial ekonomi masyarakat sekitar sebagai dasar pengelolaan populasi dan mitigasi konflik macan tutul jawa (Panthera pardus melas) di Gunung Sawal, Ciamis, Jawa Barat. Tidak diterbitkan. Retrieved in July 26, 2020 from http://bbksdajabar.ksdae.menlhk.go.id/ wp-content/uploads/2017/08/LAPORANFINAL-SURVEY-MITIGASI-KONFLIKMATUL-GUNUNG-SAWAL-20-8-2017.pdf

Treves, A., Naughton-Treves, L., \& Wallace, R. B. (2006). Co-managing human-wildlife conflicts: a review. Human Dimensions 
of Wildlife, 11(6), 383-396. https://doi. org/10.1080/10871200600984265.

WWF. (2018). Macan tutul. Retrieved September 26, 2020 from https://www.wwf.id/publikasi/ macan-tutul.

Zabala, A. (2019). Cookbook. Retrieved September 26, 2020 from https://github.com/aiorazabala/ qmethod/wiki/Cookbook.

Zabala, A., Sandbrook, C., \& Mukherjee, N. (2018). When and how to use Q methodology to understand perspectives in conservation research. Conservation Biology, 32(5), 11851194. https://doi.org/10.1111/cobi.13123. 